\title{
First record of Ustilago sporoboli-indici in Australia
}

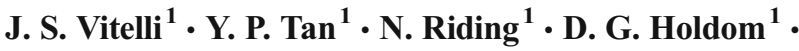 \\ A. Chamberlain ${ }^{1} \cdot$ R. G. Shivas ${ }^{1}$
}

Received: 15 August 2017 / Accepted: 11 September 2017 /Published online: 16 September 2017

(C) Australasian Plant Pathology Society Inc. 2017

\begin{abstract}
A leaf smut fungus was collected on Sporobolus natalensis (Giant Rat's Tail grass) from two locations in Queensland during early 2017. The fungus was identified as Ustilago sporoboli-indici based on morphological and DNA sequence data. This is the first record of U. sporoboli-indici in Australia.
\end{abstract}

Keywords Leaf smut fungus · Ustilago sporoboli-indici . Sporobolus $\cdot$ Giant Rat's Tail grass $\cdot$ Sporobolus natalensis

Sporobolus (Poaceae) is a genus of about 200 grass species in tropical and subtropical parts of the world, including Africa, temperate and tropical Asia, Australasia, North and South America (Simon and Jacobs 1999; TPL 2013; WCSP 2017). In Australia, 18 species are endemic, and a further six species are naturalised weeds (AVH 2017). The genus Sporobolus has been divided into a number of sections of closely allied species (Peterson et al. 2014; Simon and Jacobs 1999), including the $S$. indicus complex, which comprises of 23 to 25 species (Clayton 1965; Peterson et al. 2014). In Australia, the $S$. indicus complex includes five introduced weedy species, S. africanus (Parramatta grass), S. fertilis (Giant Parramatta Grass), S. jacquemontii (American Rat's Tail grass), S. natalensis and S. pyramidalis (Giant Rat's Tail Grass), as well as five native species, S. blakei, S. creber, S. elongatus,

J. S. Vitelli

joseph.vitelli@daf.qld.gov.au

1 Department of Agriculture and Fisheries, Biosecurity Queensland, Ecosciences Precinct, Dutton Park, QLD 4102, Australia
S. laxus and S. sessilis (Clayton 1965; Peterson et al. 2014; Simon and Jacobs 1999).

The weedy Sporobolus grasses are of serious concern to the grazing industry of eastern Australia, having the potential to infest $60 \%$ of Queensland and $30 \%$ of Australia over a range of soil types, where the annual rainfall is greater than $500 \mathrm{~mm}$, at an estimated cost of $\$ 60$ million per annum (Bray and Officer 2007). In Australian rangelands, Sporobolus species are not considered desirable pasture grasses and are indicative of a degraded grazing system in which these grasses completely dominate pastures at the exclusion of most other grass species (Burrows et al. 1988; Shrestha et al. 2003). The few native species regarded as favourable fodder species, S. actinocladus, S. caroli, S. mitchellii and $S$. virginicus, have high protein-content when fresh, but do not provide bulk (Simon and Jacobs 1999). A further two of the native species, $S$. disjunctus and S. partimpatens, are considered rare (Simon 1993), and S. pamelae is listed as endangered in Schedule 2 of the Queensland Nature Conservation Act 1992.

A leaf smut was found by one of the authors (JSV), on several plants of $S$. natalensis at a property at Taunton, central Queensland in Feb. 2017, during a survey for endemic pathogens on native and introduced Sporobolus species. A second collection of $U$. sporoboli-indici was made on leaves of $S$. natalensis from a grazing property at Conondale, southeast Queensland in June 2017. The two locations are $350 \mathrm{~km}$ apart. Specimens were deposited in the Queensland Plant Pathology Herbarium as BRIP 65466 and BRIP 66039, respectively.

Symptoms on $S$. natalensis were distorted or misshapen inflorescences and black striae on the leaf blades that produced masses of black powdery spores (Fig. 1a and b). Infected plants had fewer inflorescences compared to adjacent healthy plants. Anecdotal evidence from the landowner 

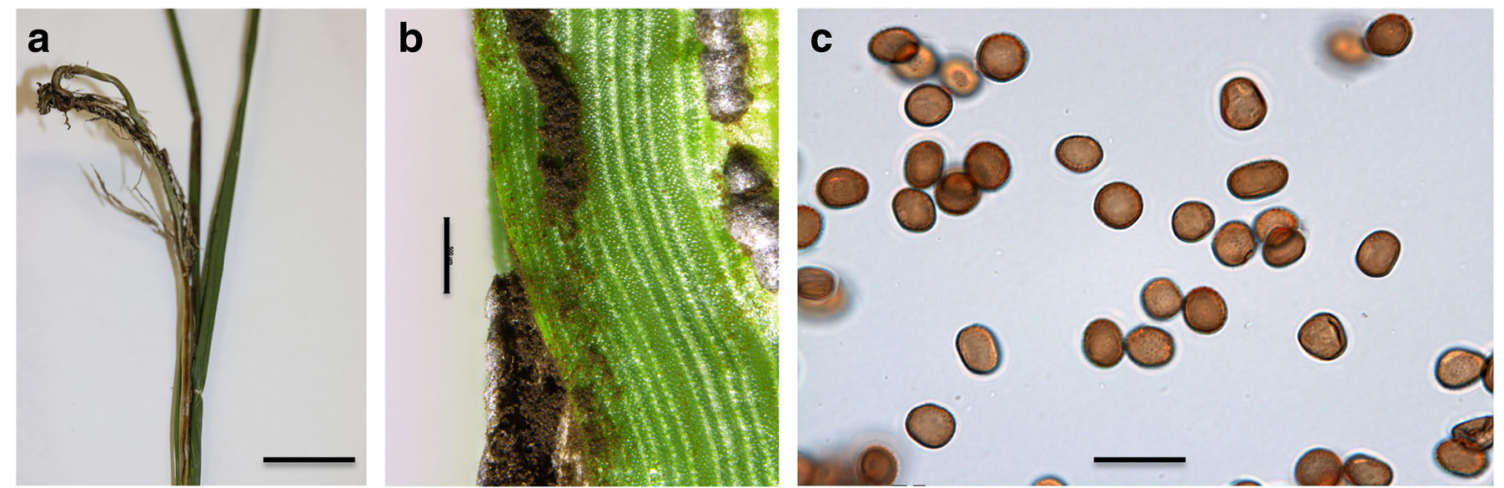

Fig. 1 Ustilago sporoboli-indici (BRIP 65466). a Inflorescence and leaves of S. natalensis infected with leaf smut. b Sori, and $\mathbf{c}$ Teliospores. Bar $=2 \mathrm{~cm}$ $(a), 500 \mu \mathrm{m}(b)$ and $10 \mu \mathrm{m}(c)$

suggested that the fungus had been present on the Taunton property for at least five years. The smut was morphologically identified as Ustilago sporoboli-indici, which is characterised by yellowish-brown spores (Fig. 1c) that are either globose, subglobose, ovoid or ellipsoidal, 6.5-11.5 × 5.5-9.5 $\mu \mathrm{m}$, with finely punctate or moderately densely verrucose-echinulate walls uniformly $0.5--0.8 \mu \mathrm{m}$ thick (Vanky 2003). Vanky (2003) reported 25 Sporobolus species infected by 17 smut fungi belonging to the genera Anthracocystis (2), Jamesdicksonia (3), Macalpinomyces (3), Tilletia (1), Tranzscheliella (1) and Ustilago (7). Five Sporobolus species, S. africanus, S. elongatus, S. indicus, S. natalensis and $S$. pyramidalis, have been recorded as natural hosts of Ustilago sporoboli-indici in Africa, China and the Philippines (Vanky 2012). Other species, S. fertilis, $S$. natalensis, $S$. sessilis and $S$. scabridus, were shown as hosts in artificial inoculation tests in South Africa (Yobo et al. 2009).

The morphological identification of $U$. sporoboli-indici was confirmed by comparing the DNA sequence of the Australian specimen BRIP 65466 with a South Africa specimen, BRIP 39706 (duplicate of HUV 20154) found on S. pyramidalis. Fungal spores were macerated with $0.5 \mathrm{~mm}$ glass beads in a Tissue Lyser (Qiagen). Genomic DNA was extracted with the DNeasy Plant Mini Kit (Qiagen) according to the manufacturer's instructions. The primers V9G (de Hoog and van den Ende 1998) and ITS4 (White et al. 1990) were used to amplify the internal transcribed spacer (ITS) region, and the primers LR0R and LR5 (Schoch et al. 2012) were used to amplify partial region of the large subunit (LSU) of the nuclear ribosomal RNA. All loci were amplified with the Phusion High-Fidelity PCR Master Mix (New England Biolabs). The PCR products were purified and sequenced by Macrogen Incorporated (Seoul, Korea). The ITS and LSU sequences, BRIP 65466, (GenBank accession MF716451, and MF716450, respectively) and BRIP 39706 (GenBank accession AY772736, and MF716449) were identical.
To date, there are 33 endemic or introduced species of Ustilago recorded in Australia (Shivas and Vanky 2003; Shivas et al. 2014). This paper reports an additional Ustilago, the first record of U. sporoboli-indici in Australia. Ustilago sporoboli-indici was investigated in South Africa as a potential biological control agent for weedy Sporobolus species in Australia (Yobo et al. 2009). The systemic smut fungus produced sori in the leaves, leaf sheaths and stems, rendering the infected plant shoots sterile (Cunnington and Shivas 2006). The ability of this smut to infect a great number of shoots indicated that it had potential as a classical biocontrol agent in Australia.

However, U. sporoboli-indici was found to infect four Australian native Sporobolus species, S. creber, S. elongatus, $S$. scabridus and $S$. sessilis, and was rejected as a potential biological control agent due to its non-selectivity (Palmer 2008).

Acknowledgments Authors would like to acknowledge the financial support from Rural Industries Research and Development Corporation (RIRDC) under the R\&D for Profit Program through the Department of Agriculture and Water Resources, and the Queensland Department of Agriculture and Fisheries, New South Wales Department of Primary Industries, NSW Weed Biocontrol Taskforce (via Rous County Council), Bundaberg Regional Council, Gladstone Regional Council and HQ Plantations for providing additional funds to investigate endemic Australian pathogens to Sporobolus grasses that could be effective against weedy Sporobolus grasses. The authors would like to thank Trevor Dawson and Brett Cawthray for assisting in the collection of plant specimens.

\section{References}

AVH (2017) Atlas of living Australia (AVH). Australia's virtual herbarium, Council of Heads of Australasian Herbaria http://avh.chah.org. au. Accessed 7 Sept 2017

Bray S, Officer D (2007) Weedy Sporobolus grasses: best practice manual. Department of Primary Industries and Fisheries, Brisbane https://futurebeef.com.au/wp-content/uploads/2011/09/Weedy sporobolus_manual.pdf. Accessed 7 Sept 2017 
Burrows WH, Scanlan JC, Rutherford MT (1988) Native pastures in Queensland. The resources and their management. Department of Primary Industries and Fisheries, Brisbane

Clayton WD (1965) Studies in the Gramineae: VI. Kew Bull 19:287-296

Cunnington JG, Shivas RG (2006) Phylogenetic considerations for predicting the host range of Ustilago sporoboli-indici, a potential biological control agent for Sporobolus species in Australia. PPQ 21:7-9

de Hoog GS, van den Ende AHG (1998) Molecular diagnostics of clinical strains of filamentous Basidiomycetes. Mycoses 41:183-189

Palmer WA (2008) Biological control of weedy Sporobolus grasses by two host specific agents. Meat livestock Australia Project code NBP.337. https://mla.com.au/download/finalreports?itemId=964. Accessed 7 Sept 2017

Peterson PM, Romaschenko K, Arrieta YH, Saarela JM (2014) A molecular phylogeny and new subgeneric classification of Sporobolus (Poaceae: Chloridoideae: Sporobolinae). Taxon 63:1212-1243

Schoch CL, Seifert KA, Huhndorf S, Robert V, Spouge JL et al (2012) Nuclear ribosomal internal transcribed spacer (ITS) region as a universal DNA barcode marker for fungi. Proc Natl Acad Sci U S A 109:6241-6246. https://doi.org/10.1073/pnas.1117018109

Shivas RG, Vanky K (2003) Biodiversity of Australian smut fungi. Fungal Divers 13:137-152

Shivas RG, Beasley DR, McTaggart AR (2014) Online identification guides for Australian smut fungi (Ustilaginomycotina) and rust fungi (Pucciniales). IMA Fungus 5:195-202 http://collections.daff.qld. gov.au/web/key/smutfungi/Media/Html/browse.html. Accessed 7 Sept 2017

Shrestha S, Adkins SW, Graham GC, Loch DS (2003) Phylogeny of the Sporobolus indicus Complex, based on internal transcribed spacer
(ITS) sequences. Aust Syst Bot 16:165-176. https://doi.org/10. 1071/sb02009

Simon BK (1993) Studies in Australian grasses, $7^{1}$. Four new species of Sporobolus R. Br. (Poaceae, Chloridoideae, Sporoboleae) from Australia. Austrobaileya 4:56-66

Simon BK, Jacobs SWL (1999) Revision of the genus Sporobolus (Poaceae, Chloridoideae) in Australia. Aust Syst Bot 12:375-448. https://doi.org/10.1071/sb97048

TPL (2013) Version 1.1. The plant list. A working list of all species. http:// www.theplantlist.org/tp11.1/search?q=Sporobolus. Accessed 7 Sept 2017

Vanky K (2003) The smut fungi (Ustilaginomycetes) of Sporobolus (Poaceae). Fungal Divers 14:205-241

Vanky K (2012) Smut fungi of the world. APS Press, St. Paul

WCSP (2017) World checklist of selected plant families (WCSP) (version $25^{\text {th }}$ August 2017). Species 2000 \& ITIS catalogue of life. In: Roskov Y, Abucay L, Orrell T, Nicolson D, Bailly N, Kirk PM, Bourgoin T, DeWalt RE, Decock W, de Wever a, Nieukerken E. Van, Zarucchi J, Penev L (eds). http://catalogueoflife.org/col . Accessed 7 Sept 2017

White TJ, Bruns T, Lee S, Taylor J (1990) Amplification and direct sequencing of fungal ribosomal RNA genes for phylogenetics. In: Innis MA, Gelfand DH, Sninsky JJ, White TJ (eds) PCR protocols: a guide to methods and applications. Academic, San Diego, pp 315322

Yobo KS, Laing MD, Palmer WA, Shivas RG (2009) Evaluation of Ustilago sporoboli-indici as a classical biological control agent for invasive Sporobolus grasses in Australia. Biol Control 50:7-12. https://doi.org/10.1016/j.biocontrol.2009.01.006 